\title{
Operational Risk in Both Conventional and Islamic Banking Perceptions: Differences and Similarities
}

\author{
Salma Rhanoui, (PhD Student) \\ Khalid Belkhoutout, (Professor of Higher Education) \\ Mohammed V University - Rabat, Faculty of Law, \\ Economics and Social Sciences - Souissi, Morocco
}

Doi: 10.19044/esj.2018.v14n13p110 URL:http://dx.doi.org/10.19044/esj.2018.v14n13p110

\begin{abstract}
While risks in conventional banks have been meticulously discussed in the literature, they remain a fresh research area in Islamic banks. In this context, operational risk has long been considered a simple part of "other" risks outside the dominion of credit risk and market risk, before it made its way to the forefront of banking. In fact, with the rise and enlargement of the Islamic banking industry and its unique contractual features and legal environment, operational risk has become more wide-ranging in Islamic banks compared to conventional banks. In this sense, the following work aims to provide a comparison of operational risk perceptions in both conventional and Islamic banks, with the objective of determining the fundamental similarities and differences of this risk within each system, which can be seen as a boosting step meant to help creating a good risk management tactics in both banks. This work showed a difference regarding the two definitions of operational risk. It also demonstrated that the conventionnal and Islamic banking systems are similar while presenting some differences in terms of components and factors of opeational risk.
\end{abstract}

Keywords: Conventional banking, Differences, Islamic banking, Operational risk, Similarities

\section{Introduction}

The relatively young Islamic banks have coexisted or even competed with the conventional banks that have always been present, which suggests a certain relevance in the management of Islamic banking risks.

Compared to conventional banks, operational risks faced by the Islamic banks are more diverse. In principle, the operational risk attached to a business is tremendously reliant on the business processes used by the organization (Wahyudi, Rosmanita, Prasetyo, \& Putri, 2015). Even if the 
business processes of both an Islamic and a conventional bank are approximately the same, there are many differences between the banks.

In this sense, this work attempts to answer the following question: What are the similarities and differences of operational risk in both conventional and Islamic banking systems?

This paper is divided into three main parts. First, this work will clarify the notions of risk and Islamic banking. The second part will highlight the place of operational risk among all banking risk, while the third section will provide a comparison of the perceptions of both conventional and Islamic banks regarding this risk in terms of definition, components and factors.

\section{Notions of risk and Islamic banking}

The meaning of "risk" is obvious and is essentially the same as what is understood in everyday conversation. "There is risk involved with a certain situation" refers to a state where there is uncertainty as to the occurrence of the anticipated results and the probability that the consequence will be something that is not wanted (Elgari, 2003). This significance is precisely what is meant by risk in financial literature, it refers to a situation in which two or more results are possible. It is plain that situations in which there is the possibility of only one consequence are situations that have no risk.

Risk is consequently the vital element that disturbs financial comportment. In the banking sector, the risks could, for example, be (Thijs, 2010):
$\checkmark \quad$ A borrower defaulting on repaying a credit;
$\checkmark \quad$ Fluctuation of exchange rates;
$\checkmark \quad$ Fraud or incomplete security documentation;
$\checkmark \quad$ Failure to respect the principles of Shari'a (Islamic law);
$\checkmark \quad$ Other events that could lead to a loss for the bank.

An Islamic bank is a financial institution whose rules and procedures are in accordance with Shari'a.

Islamic banking is a basically normative concept and can be seen as conducting banking in consonance with the code of the Islamic value system. Thus, Islamic banking is a system of financial intermediation that evades the payment and receipt of interest in its operations and conducts its transactions in a manner that helps reach the objectives of an Islamic Economy (El-Gawady, 2008). In other words, Islamic banking is a system in which profit and loss sharing (PLS) is one of the main features, guaranteeing equity and justice in the economy. This feature is why Islamic banks are frequently known as PLSbanks.

The principles of the Islamic banking system are schematized by the Figure 1 below: 


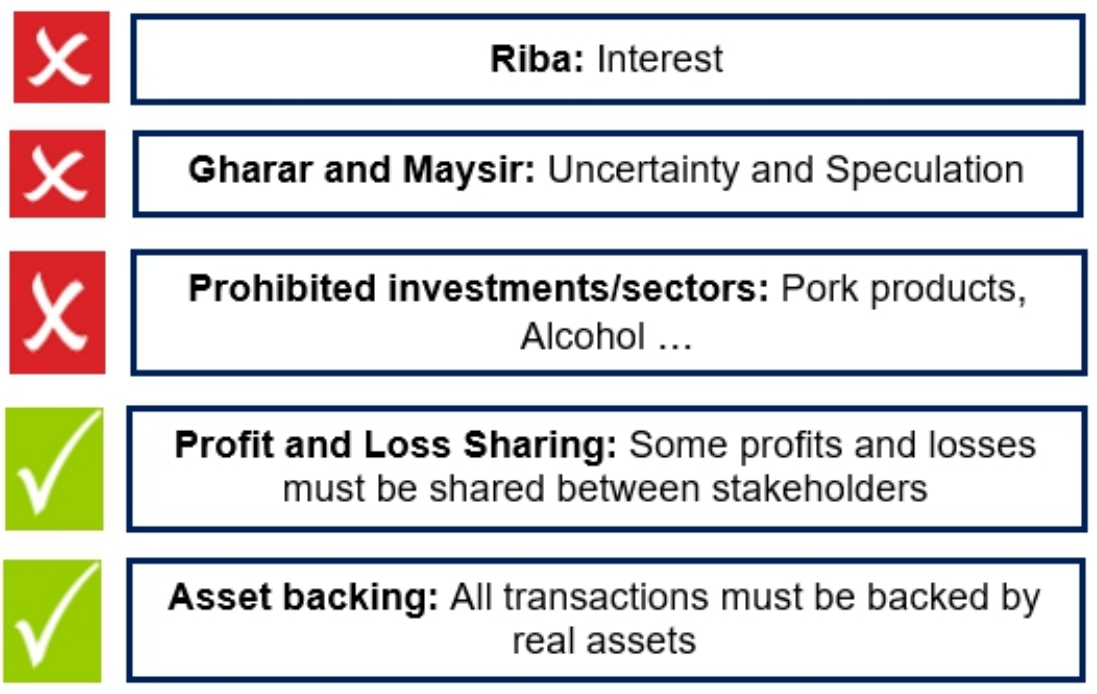

Figure 1: Islamic banking principles

Source: Author

The principles of Islamic banking consist of three prohibitions and two obligations that must be followed by Islamic banks in their daily practices. The overriding principle in risk management practice is the PLS, which plays an important role in mitigating the risks faced by Islamic banks. In the case of operational risk, the prohibition of Gharar plays an important role in risk mitigation for Islamic banks, unlike conventional banks that do not follow any particular mode of operation.

\section{Place of operational risk among all banking risks}

Islamic banks face the same types of risks that conventional banks do (Raouf, 2013). However, in addition to those generic risks, Islamic banks face specific risks due to the peculiarity of their financial products, the nature of the transaction, the maturities and the structure of the bank's balance sheets.

Figure 2 below marks the similar, generic types of risk and the additional, different risks encountered by conventional and Islamic banks: 


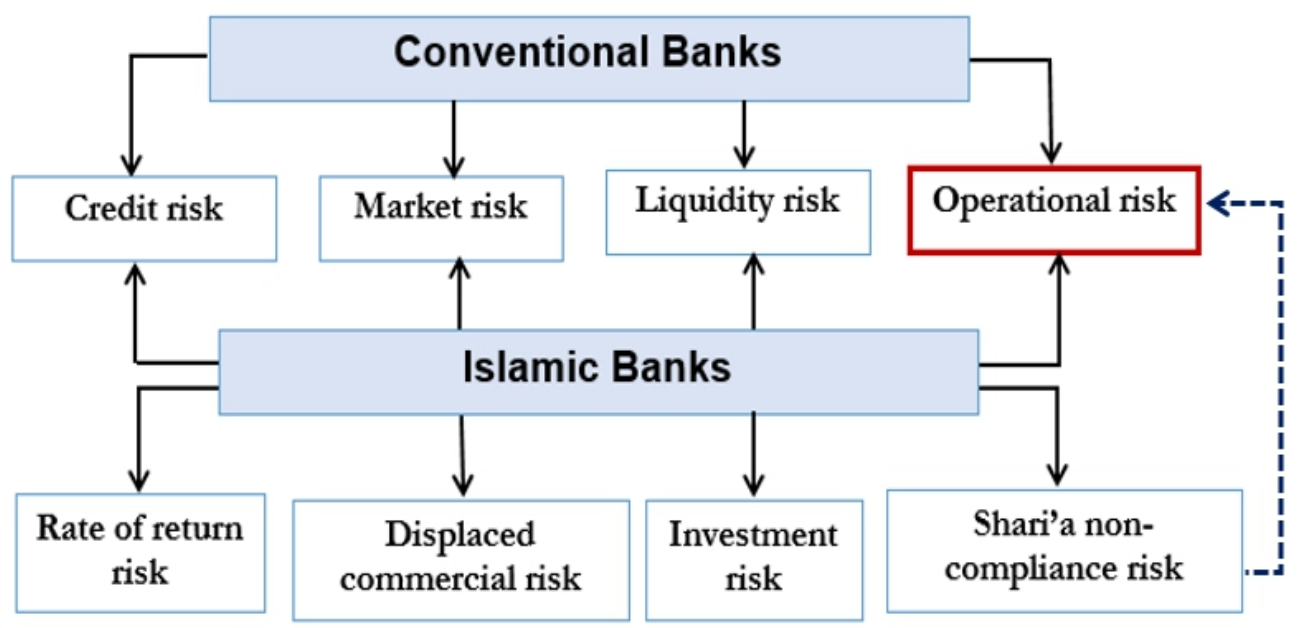

Figure 2: Conventional and Islamic banking risks

Source: Author

According to Figure 2, operational risk is a common risk between Islamic banks and their conventional counterparts. However, as will be demonstrated later, the Islamic banking perception considers Shari'a noncompliance risk (which is specific to Islamic banks) an operational risk.

\section{Operational risk in both conventional and Islamic banking environments}

As previously stated, the comparison of operational risk between the two banking industries focuses on operational risk definitions, components and factors.

\section{Comparison of definitions}

The definition of operational risk has changed over the past few years. Initially, it was defined as every unquantifiable risk faced by banks. However, additional analysis has sophisticated the definition (Dar, Azeem, \& Masood, 2013). Operational risk was defined by the Basel Committee on Banking Supervision (BCBS) for conventional banks, and by the Islamic Financial Services Board (IFSB) for Islamic banks.

Table 1 below compares the two operational risk definitions:

Table 1: Operational risk definition in both conventional and Islamic banking

\begin{tabular}{cc}
\hline $\begin{array}{c}\text { Conventional banking } \\
\text { (Basel II) }\end{array}$ & $\begin{array}{c}\text { Islamic banking } \\
\text { (IFSB) }\end{array}$ \\
\hline $\begin{array}{c}\text { Operational risk is "the risk of loss resulting } \\
\text { from inadequate or failed internal processes, } \\
\text { people and systems or from external events." }\end{array}$ & $\begin{array}{c}\text { Operational risk is “the risk related to the loss } \\
\text { resulting from inadequate or failed internal } \\
\text { processes, people and system, or from external } \\
\text { events, including losses resulting from Shari'a } \\
\text { non-compliance and the failure in fiduciary } \\
\text { responsibilities." }\end{array}$ \\
\hline
\end{tabular}


The Basel II definition of operational risk embraces legal risk, but excludes reputational risk. This definition is also causal-based, providing a breakdown of operational risk into four classes based on the source of the risks (Chernobai, Rachev, \& Fabozzi, 2008): (1) people, (2) processes, (3) systems, and (4) external factors.

It is understood that the IFSB's definition of operational risk involves legal risk, and reputational risk. Nevertheless, the distinctive feature of this definition, as compared to the definition by Basel II, is the inclusion of Shari'a non-compliance risk and fiduciary risk. Shari'a non-compliance risk is a major part of operational risk.

\section{Comparison of components}

Operational risk components in Islamic banks are dissimilar to those in conventional banks. Although it is claimed that the challenges are somewhat similar, they are only to the extent that Islamic banks and conventional banks handle numerous banking activities.

\section{Components of operational risk from the conventional perspective}

Basel II is the public name used to denote the document "International Convergence of Capital Measurement and Capital Standards: A Revised Framework," which was published in 2004 by the Bank for International Settlements in Europe. Basel II provides a set of seven categories of operational risk (Hull, 2012):

Internal fraud: Acts meant to deceive, steal property or avoid regulations, company policy or the law. Examples include insider trading on an employee's own account, employee theft and intentional misreporting of positions;

External fraud: Acts by a third party intended to swindle, avoid the law or to misappropriate property. Examples encompass damage from computer hacking, check kiting, robbery and forgery;

Employment practices and workplace safety: Unpredictable acts concerning health, safety agreements or employment, which result in the payment of personal wound claims or claims relating to multiplicity or discrimination issues. Examples comprise general liability, workers' compensation claims, discrimination claims, violation of employee safety rules and organized labor activities;

Clients, products, and business practices: Unintended or neglectful failure to meet a professional obligation to explicit clients, or due to the nature or design of a product. Examples include misappropriation of confidential customer information, fiduciary breaches and money laundering; 
Damage to physical assets: Loss or damage to physical assets from natural catastrophes or other events. For instance, vandalism, earthquakes and fires;

Business disruption and system failures: Examples comprise software failures, telecommunication difficulties and utility outages;

Execution, delivery, and process management: Fruitless transaction processing or process management, or relations with trade counterparties and vendors. Examples are data entry faults, unfinished legal documentation, unapproved access given to clients' accounts and vendor disputes.

\section{Components of operational risk from the Islamic perspective}

For Islamic banks, the IFSB and literature suggest that operational risk exposures could appear based on the following six main sources:

External events risk is the risk that may occur from external incidents such as external fraud, regulatory regime change, computer hacking and other causes beyond the control of the Islamic bank (Dar et al., 2013);

Shari'a non-compliance risk is the risk of an Islamic bank's failure to comply with Shari'a principles determined by the Shari'a board of the IIFS (institutions, other than insurance institutions, offering only Islamic financial services). However, this definition situates the responsibility of Shari'a noncompliance risk exclusively on the Islamic bank and does not address the probable failure of the Shari'a board to offer a rigorous resolution in cases in which the Shari'a board switches stances or amends its resolution because of the absence of information provided or due to other reasons. The proper definition of Shari'a non-compliance risk should consequently be as follows (Lahsasna, 2014):

"Shari'a non-compliance risk is the risk that arises from (1) Islamic bank's failure to comply with the Shari'a principles determined by the Shari'a board or, (2) failure of the Shari'a board to offer a sound resolution due to the deficiency of information provided to them or due to other reasons".

Examples include exchange of money for money instead of assets in Murabaha, incapacity of payment in advance in Salam and assets rental for Shari'a non-compliance purposes in Ijara (Izhar, 2010);

Fiduciary risk is an Islamic bank's failure to perform in accordance with explicit and implicit standards applicable to their fiduciary responsibilities. The sign of such failure can be perceived from the important degree of their earnings volatility (Izhar, 2012). As a result of losses, Islamic banks may become insolvent. Examples take account of substandard products delivery in Murabaha, non-respect of products quality level in Istisna' and the Islamic bank's failure in maintaining the leased asset in Ijara (Izhar, 2010);

People risk refers to losses from actions such as violations of internal rules and procedures, frauds and human errors, and more commonly problems of ineffectiveness and carelessness of the bank human resources (Izhar \& 
Hassan, 2013). People risk in Islamic banks is significantly higher than in conventional banks because the staff needs to have knowledge of both Islamic and conventional banks. Islamic banks need to be prepared with new innovators and product developers who have a solid understanding of Shari'a and are aware of the commercial advantages and disadvantages of Islamic products over the conventional products (Arif, Jan, \& Kulsoom, 2016).

Examples comprise rent increase by the lessor in case of late payment in Ijara, inability to provide a regular financial performance of the project in Mudaraba and incapacity to deliver the product on time in Istisna'(Izhar, 2010);

Technology risk: Islamic bank's transactions are greatly reliant on its technological system. Its success highly depends on its ability to collect progressively rich databases and make appropriate decisions in anticipation of client demands and industry changes. The success of an Islamic bank's business is oftentimes determined by the bank's ability to exploit the use of information technology (IT) in different ways (Izhar, 2010). An incapability to keep up with the advanced use of IT could cause an Islamic bank fall behind its competitors. For instance, accounting software incompatibility with Islamic banking contracts features;

Legal risk: With the development of new products, the freshly adaptive techniques of Islamic banks significantly expose these banks to legal risk. Most Islamic banks are operating across different countries with dissimilar legal systems. Banks are typically exposed to country-specific risks that vary from one place to another (Arif et al., 2016). Hence, it can be claimed that doubts in law, unexpected changes in regulation and uncertainty in understanding various Islamic contracts, will all cause Islamic banks to have legal risk. Examples include nonexistence of agreement on the remedies for the defects of the good in Istisna' and civil laws misinterpretation regarding implementation of contracts in Mudaraba (Izhar, 2010).

Table 2 below summarizes the characteristics of operational risk in both conventional and Islamic banking systems.

Table 2: Operational risk components in both conventional and Islamic banking systems

\begin{tabular}{|c|c|c|}
\hline & $\begin{array}{c}\text { Conventional banking } \\
\text { (Basel II) }\end{array}$ & $\begin{array}{c}\text { Islamic banking } \\
\text { (IFSB and literature) }\end{array}$ \\
\hline $\begin{array}{l}\text { Nature of the } \\
\text { components }\end{array}$ & Categories & Sources or aspects \\
\hline $\begin{array}{l}\text { Number of } \\
\text { components }\end{array}$ & Seven & Six \\
\hline $\begin{array}{l}\text { Presentation of the } \\
\text { components }\end{array}$ & $\begin{array}{c}\text { (1) Internal fraud } \\
\text { (2) External fraud } \\
\text { (3) Employment practices and } \\
\text { workplace safety } \\
\text { (4) Clients, products, and business } \\
\text { practices } \\
\text { (5) Damage to physical assets } \\
\text { (6) Business disruption and system } \\
\text { failures }\end{array}$ & $\begin{array}{l}\text { (1) External events risk } \\
\text { (2) Shari'a non-compliance risk } \\
\text { (3) Fiduciary risk } \\
\text { (4) People risk } \\
\text { (5) Technology risk } \\
\text { (6) Legal risk }\end{array}$ \\
\hline
\end{tabular}


(7) Execution, delivery, and process management

Example of each component
(1) Employee theft

(2) Computer hacking

(3) Violation of employee safety rules

(4) Misuse of confidential customer information

(5) Vandalism

(6) Software failures

(7) Data entry errors
(1) Regulatory regime change

(2) Assets rental for Shari'a noncompliance purposes

(3) Non-respect of products quality level

(4) Product delivery failure

(5) Accounting software incompatibility with contracts features

(6) Civil laws misinterpretation regarding implementation of contracts

\section{Source: Author}

This table shows that operational risk components differ between the two banking systems, whether in terms of the nature, number, or presentation of the components. However, apart from external events risk for Islamic banks, and external fraud alongside unintentional damage to physical assets for conventional banks, operational risk occurs according to contracts characteristics in Islamic banks, which is not the case for conventional banks, in which this risk remains the same in all transactions.

\section{Comparison of factors}

When even large and old conventional banks can easily collapse due to operational risks, it shows that Islamic banks are still powerlessly exposed to operational risk. Awareness of operational risk starts with building awareness to latent risk factors. These factors can originate from something seemingly trivial to something that appears unsafe from the beginning.

Figure 3 below shows the different factors that could generate operational risk for both conventional banks (CBs) and Islamic banks (IBs). Like risks, there are both commonly held factors and factors specific to Islamic banks.

\section{External factors of operational risk}

- Economic environment

- Regulation changes IBs \& CBs

\section{Internal factors of operational risk}

- The quality of the bank's human resources

- Business disruption and Information Technology system failures IBs \& CBs

- The nature of the bank's activities IBs

Figure 3: Operational risk factors in both conventional and Islamic banking Source: Author 


\section{External factors}

In this context, operational risk come from outside the bank. External factors are, therefore, common for Islamic banks and their conventional counterparts.

One external source of risk is the economic environment. Changes in the economic environment can impact the volume of activity and the likelihood of the borrowers defaulting (Laycock, 2014). At the extreme, the economic environment can influence the provision of services by merchants, particularly if the vendor goes bankrupt. Some external risks may be amplified by the economic environment. For instance, criminal activity such as fraud can upsurge with an economic downturn.

An additional external operational risk factor is the regulation changes. This concept refers to actions by governments and their numerous agents, such as regulators (Laycock, 2014). These actions can be initiated due to the idea that banking services are common goods that are vital for the smooth functioning of society. A response to the global financial crisis has been the enlargement and publication of further regulatory requirements for banks. Some of these added requirements have been published at the international level and others at the national level.

\section{Internal factors}

In this case, operational risk comes from inside the bank and tends to be people-related, in particular, due to staff. Internal factors can be either common between the two categories of banks, or specific to Islamic banks.

One of these internal factors is the quality of the bank's human resources. Lack of competency in the area of banking is undeniably a main factor of operational risk, especially in Islamic banks. If the bank's officer does not have the required knowledge and skills according to the job description, the chance of operational risk is high (Lahsasna, 2014). Hence, proper knowledge according to specific qualifications is needed to perform sound banking activities.

Another internal factor of operational risk is business disruption and IT system failures. This factor refers to operational losses associated with IT, caused or related to software or hardware complications (Soprano, Crielaard, Piacenza, \& Ruspantini, 2010). For such events, the severity is frequently difficult to measure, as they are tied to internal resources such as help desks and maintenance teams.

Operational risk can also emerge from the nature of the bank's activities, and it is unique to Islamic banking institutions. Unlike conventional banks, ensuring Shari' a compliant aspect is vital for Islamic banks to preserve the confidence level of their customers and the general public. Insufficient 
attention to Shari'a compliance can trigger negative consequences for Islamic banking institutions, such as significant withdrawals and financial loss.

\section{Conclusion}

Operational risk is essential in all banking activities, products, processes and systems, and the sound management of operational risk has always been a significant pillar of every financial institution (Basel Committee, 2011).

Operational risk management is consequently a challenging task for both conventional and Islamic banks to diminish the chances of losses incurred due to internal human errors, technological faults, fraud, or violations of the precise guidelines recommended by regulatory authorities (Arif et al., 2016). In this sense, because of the unique and refined nature of the contractual features of Islamic banks, and with the rising demand of numerous products in the Islamic banking sector, it is complex for Islamic banks to manage their operational risks.

Thus, understanding the differences and similarities of operational risk in both conventional and Islamic banking systems is a stimulating task due to the various aspects it entails. Therefore, this understanding should be regarded as a structured step that will help Islamic and conventional banks develop more suitable risk management plans.

It is the author's hope that this work contributes to a better understanding of the subject and leads to more systematic studies of this area in the future.

\section{References:}

1. Arif, M., Jan, S., \& Kulsoom, A. (2016). Operational Risk Exposure to Islamic Banks.

2. Basel Committee. (2011). Principles for the Sound Management of Operational Risk. Basel, Switzerland: Bank for International Settlements Communications.

3. Chernobai, A. S., Rachev, S. T., \& Fabozzi, F. J. (2008). Operational risk: a guide to Basel II capital requirements, models, and analysis (Vol. 180). John Wiley \& Sons.

4. Dar, M. R., Azeem, M., \& Masood, O. (2013). Operational Risk Management, Risk Management Approaches, and Risk Mitigation Techniques: Challenges Faced By Islamic Financial Services, 11(2), 72-79.

5. Elgari, M. A. (2003). Credit risk in Islamic banking and finance. Islamic Economic Studies, 10(2), 1-25. 
6. El-Gawady, Z. M. (2008). Possibility of Cooperation between Islamic Banks and Conventional Banks. Misr university for Science and Technology, Giza, Egypt, Rep.

7. Hull, J. (2012). Risk management and financial institutions (Vol. 733). John Wiley \& Sons.

8. Izhar, H. (2010). Identifying operational risk exposures in Islamic banking. Kyoto Bulletin of Islamic Area Studies, 3(2), 17-53.

9. Izhar, H. (2012). Measuring Operational Risk Exposures in Islamic Banking: A Proposed Measurement Approach, 20(1).

10. Izhar, H., \& Hassan, Z. S. A. (2013). Applying Core Principles of Risk Management in Islamic Banks' Operational Risk Analysis. Afro Eurasian Studies, 2(1/2), 15-40.

11. Lahsasna, A. (2014). Shari'ah Non-Compliance Risk Management and Legal Documentation in Islamic Finance. John Wiley \& Sons.

12. Laycock, M. (2014). Risk management at the top: a guide to risk and its governance in financial institutions. John Wiley \& Sons.

13. Raouf, H. (2013). Risk Management Practices in both Conventional and Islamic Finance: A comparative Study. Mohammadia School of Engineering, Mohammed V University Rabat.

14. Soprano, A., Crielaard, B., Piacenza, F., \& Ruspantini, D. (2010). Measuring Operational and Reputational Risk: A Practitioner's Approach (Vol. 562). John Wiley \& Sons.

15. Thijs, J. P. (2010). Risk Management in Islamic Banking. Bank Islam Malaysia Berhad.

16. Wahyudi, I., Rosmanita, F., Prasetyo, M. B., \& Putri, N. I. S. (2015). Risk Management for Islamic Banks: Recent Developments from Asia and the Middle East. John Wiley \& Sons. 